\title{
Nucleic Acid Testing for Diagnosis of HIV in Cases of Negative or Uncertain Antibody-Based Testing Results in China and Abroad Diagnosis in Cases of HIV Anti- body Negative or Uncertain
}

\author{
Faxin $\mathrm{Hei}^{1}$, Zhijuan $\mathrm{Li}^{2}$ and Jun $\mathrm{Hu}^{3 *}$ \\ ${ }^{1}$ National Center for AIDS/STD Control and Prevention, Chinese Center for Disease Control and Prevention, China \\ ${ }^{2}$ Blood Center For Shandong Province, China \\ ${ }^{3}$ Shandong Center for Disease Control and Prevention; Academy of Preventive Medicine, China \\ *Corresponding author: Jun Hu, Shandong Center for Disease Control and Prevention; Academy of Preventive Medicine, China
}

\section{ARTICLE INFO}

Received: 峯 July 19, 2019

Published: 幽 August 02, 2019

Citation: Faxin Hei, Zhijuan Li, Jun Hu. Nucleic Acid Testing for Diagnosis of HIV in Cases of Negative or Uncertain Antibody-Based Testing Results in China and Abroad Diagnosis in Cases of HIV Antibody Negative or Uncertain.. Biomed J Sci \& Tech Res 20(2)-2019. BJSTR. MS.ID.003423.

Keywords: HIV diagnosis; HIV seronegativity; Nucleic acid testing
ABSTRACT

Objective: To summarize the negative or uncertain HIV/AIDS cases reported in domestic and foreign literature from 1994 to 2017 and provide evidence for the diagnosis of HIV/AIDS cases. Methods By reviewing the literature, we collected antibody-negative or uncertain HIV/AIDS cases reported at home and abroad.

Results: We summarize 34 cases with seronegative or uncertain HIV antibody testing results using ELISA or WB methods, which were reported internationally between 1994 and 2017.

Conclusion: These cases demonstrate the crucial need for HIV nucleic acid qualitative or quantitative detection for diagnosis of HIV infection when antibody-based methods yield negative or uncertain results.

Abbreviations: HIV: Human Immunodeficiency Virus; AIDS: Acquired Immune Deficiency Syndrome; ELISA: Enzyme-Linked Immunosorbent Assays; WB: Western Blot; CD4: Cluster of Differentiation 4; VL: Viral Load

\section{Introduction}

Normally, HIV infections can be diagnosed with rapid tests or enzyme-linked immunosorbent assays (ELISA), and confirmed by Western blot (WB) methods. However, in rare situations where patients are not producing antibodies in sufficient quantities, these test methods yield negative or inconclusive results. These situations include acute infection, during which the well-known "window period" occurs when viral infection is newly present, but the host has not yet had enough time to generate antibodies to viral antigens Another low-antibody situation occurs when patients are in the advanced stages of AIDS and are so immunocompromised (as evidenced by their extremely low CD4 cell counts) that they fail to make enough antibodies to be detected by conventional antibody-based methods. In these extreme situations, laboratory results are not consistent with clinical manifestations, which can lead to misdiagnosis or misjudgment of prognosis [1]. In this article, we summarize previous domestic and international reports of HIV diagnosis in patients with negative or uncertain results on antibody-based HIV testing due to insufficient antibody levels [2-3].

\section{Methods}

We had a reference to the literature published in the journal AIDS in 2010 by Spivak et al. [4] which identified 25 cases of HIV infection worldwide between 1994 and 2009. Using the same method, We performed a comprehensive literature search in both Chinese, using the scientific and technological literature service system of 
the Chinese Center for Disease Control and Prevention (China CDC; http://literature.chinacdc.cn/), and in English, using the online search engine of the United States National Library of Medicine (US NLM; https://www.ncbi.nlm.nih.gov/pubmed/) between 1994 and 2017. Search terms used were "HIV seronegative" and "HIV uncertain." Articles were screened to ensure that they reported on one or more HIV cases with negative or uncertain HIV antibodybased testing results at the time of diagnosis of HIV infection.

\section{Results}
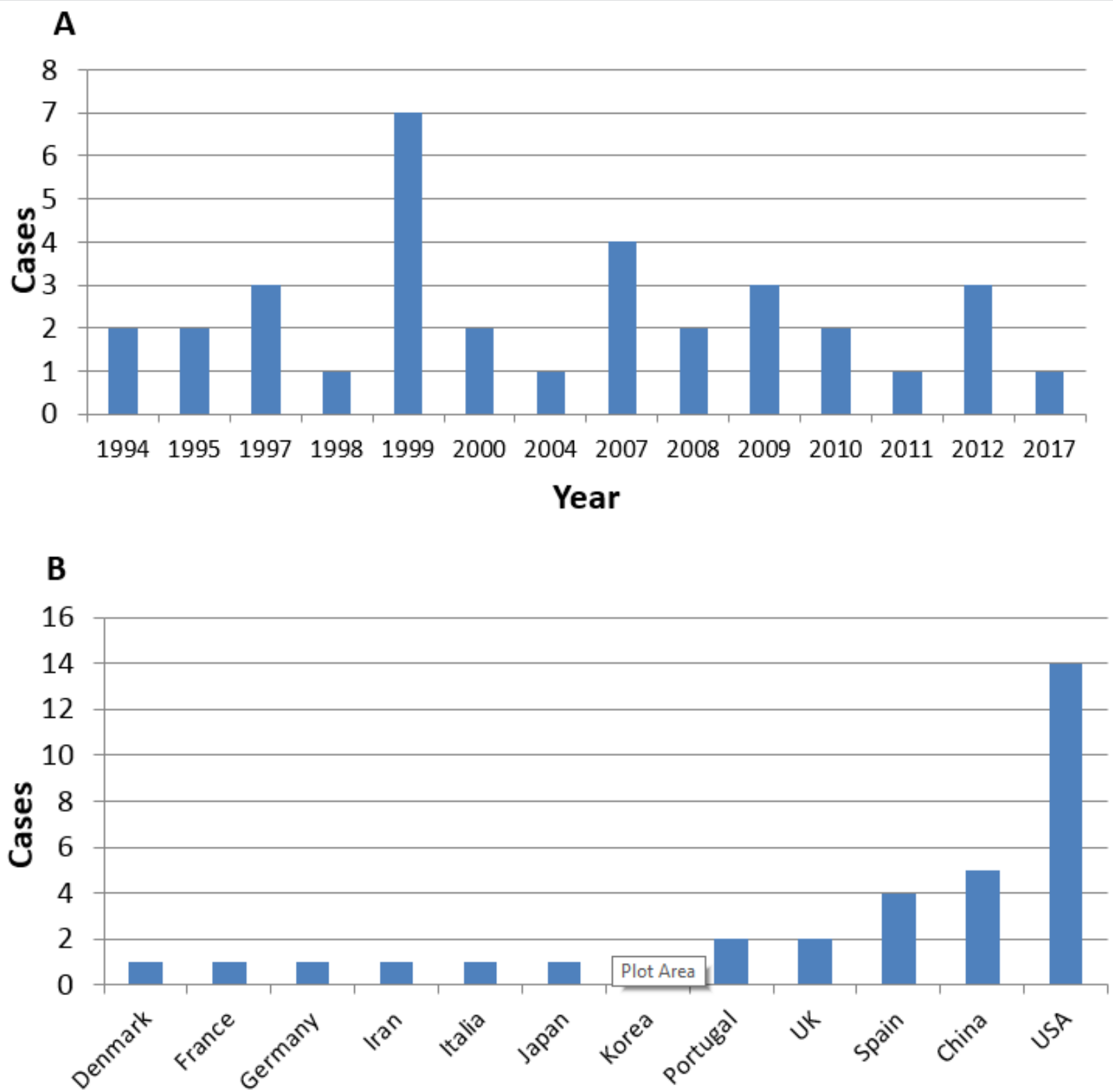

Country

Figure 1: Year [A] and country [B] of HIV cases that were either HIV-seronegative or uncertain upon initial antibody testing worldwide, 1994-2017.

\section{Included Studies}

Between 1994 and 2017, a total of 28 publications, documenting 34 individual cases, met the study eligibility criteria were included in the analysis. 5 cases were found and reported in China. In addition to the 25 cases summarized by Spivak et al., another 4 cases were reviewed and collated, they were N0.27,32-34 cases in Table 1. Demographic and clinical characteristics of all 34 cases are tabulated in Table 1, and the numbers of cases by year, and by country are plotted in Figure 1. 
Table 1: Demographics and clinical features of HIV cases that were either HIV-seronegative or uncertain upon initial antibody testing worldwide, 1994-2017.

\begin{tabular}{|c|c|c|c|c|c|c|c|c|}
\hline Case No. & $\begin{array}{c}\text { Year } \\
\text { Reported }\end{array}$ & Sex & Age & Country & $\begin{array}{l}\text { Viral Load } \\
\text { (copies/mL) }\end{array}$ & $\begin{array}{l}\text { CD4 Count } \\
\text { (cells } / \mu \mathrm{L})\end{array}$ & $\begin{array}{c}\text { HIV-Related typical } \\
\text { Complications \& } \\
\text { Opportunistic Infections }\end{array}$ & References \\
\hline \multicolumn{9}{|c|}{ Cases Reported in China } \\
\hline 1 & 2007 & Male & $37 \mathrm{yr}$ & China & 153,000 & 5 & $\begin{array}{c}\text { pneumocystis carinii } \\
\text { pneumonia }\end{array}$ & Hei Fa Xin [4] \\
\hline 2 & 2008 & Male & $16 \mathrm{mo}$ & China & 150,000 & - & oral candidiasis & Zhang Yun Zhi [5] \\
\hline 3 & 2010 & Female & $33 \mathrm{yr}$ & China & $>1,000,000$ & 7 & persistent diarrhea & Li Yan [6] \\
\hline 4 & 2012 & Male & $69 \mathrm{yr}$ & China & 72,000 & 8 & tuberculosis & Qin Ying Mei [7] \\
\hline 5 & 2017 & Male & $46 \mathrm{yr}$ & China & 42,969 & 6 & Kaposi sarcoma & Zhang Hong [8] \\
\hline \multicolumn{9}{|c|}{ Cases Reported Elsewhere } \\
\hline 6 & 1994 & Male & $26 \mathrm{yr}$ & Spain & - & 208 & tuberculosis & Soriano [15] \\
\hline 7 & 1994 & Male & $24 \mathrm{yr}$ & Japan & - & 230 & pneumocystis pneumonia & Oka [16] \\
\hline 8 & 1995 & Female & $24 \mathrm{yr}$ & USA & 105,000 & 27 & acute interstitial pneumonitis & Wegner [17] \\
\hline 9 & 1995 & Male & $19 \mathrm{yr}$ & Denmark & - & 87 & cerebral abscesses & Martin-Rico [18] \\
\hline 10 & 1997 & Male & $36 \mathrm{yr}$ & USA & - & 129 & pneumocystis pneumonia & Reimer [19] \\
\hline 11 & 1997 & Female & $38 \mathrm{yr}$ & France & $>1,000,000$ & 0 & bacillary angiomatosis & Montagnier [20] \\
\hline 12 & 1997 & Male & $31 \mathrm{yr}$ & USA & - & 230 & pneumocystis pneumonia & Michael [21] \\
\hline 13 & 1998 & Female & $4 \mathrm{mo}$ & USA & 577,697 & 10 & pneumocystis pneumonia & Quinonez [22] \\
\hline 14 & 1999 & Male & $30 s$ & USA & 337,000 & 94 & pneumocystis pneumonia & Sullivan [23] \\
\hline 15 & 1999 & Male & $30 \mathrm{~s}$ & USA & $>1,000,000$ & 15 & pneumocystis pneumonia & Sullivan [23] \\
\hline 16 & 1999 & Male & $20 s$ & USA & 773,000 & 11 & pneumocystis pneumonia & Sullivan [23] \\
\hline 17 & 1999 & Female & $10 \mathrm{~s}$ & USA & 480,000 & 8 & pneumocystis pneumonia & Sullivan [23] \\
\hline 18 & 1999 & Female & $20 s$ & USA & 254,000 & 2 & pneumocystis pneumonia & Sullivan [23] \\
\hline 19 & 1999 & Female & $29 \mathrm{yr}$ & UK & 570,000 & 100 & pneumocystis pneumonia & Rice [24] \\
\hline 20 & 1999 & - & - & USA & 38,000 & 2 & - & Ellenberger [25] \\
\hline 21 & 2000 & Female & $29 \mathrm{yr}$ & UK & - & 229 & herpes & Candotti [26] \\
\hline 22 & 2000 & Female & $2 \mathrm{mo}$ & Italy & $>1,000,000$ & 170 & neurologic symptoms & De Rossi [27] \\
\hline 23 & 2004 & Female & $29 \mathrm{yr}$ & Portugal & - & 102 & typhoid fever & Cardoso [28] \\
\hline 24 & 2007 & Male & $47 \mathrm{yr}$ & Germany & 242,287 & 2 & esophageal ulcer & Monkemuller [29] \\
\hline 25 & 2007 & Male & $37 \mathrm{yr}$ & Korea & $>1,000,000$ & 89 & diarrhea & Chin [30] \\
\hline 26 & 2007 & Female & $46 \mathrm{yr}$ & USA & $>750,000$ & 38 & weight loss & Novitsky [31] \\
\hline 27 & 2008 & Male & $28 \mathrm{yr}$ & Spain & 122,000 & 4 & Kaposi sarcoma & $\begin{array}{l}\text { Ortiz de Lejarazu } \\
\text { [32] }\end{array}$ \\
\hline 28 & 2009 & Male & $26 \mathrm{yr}$ & USA & 320,000 & 108 & pneumocystis pneumonia & Dalmau [33] \\
\hline 29 & 2009 & Female & $15 \mathrm{yr}$ & USA & 20,000 & 0 & cryptococcus & Dalmau [33] \\
\hline 30 & 2009 & Male & $29 \mathrm{yr}$ & Portugal & $>8,000,000$ & 52 & candidiasis & Bartolo [34] \\
\hline 31 & 2010 & Male & $59 \mathrm{yr}$ & USA & $>100,000$ & 90 & pneumocystis pneumonia & Spivak [35] \\
\hline 32 & 2011 & Male & $43 \mathrm{yr}$ & Iran & - & $<300$ & orbital lymphoma & Eftekhari [36] \\
\hline 33 & 2012 & Male & $55 \mathrm{yr}$ & Spain & - & 166 & bullous pemphigoid & Ollé-Goig [37] \\
\hline 34 & 2012 & Female & $30 \mathrm{yr}$ & Spain & - & 28 & diarrhea & Ollé-Goig [37] \\
\hline
\end{tabular}




\section{Cases Reported in China}

In China, Hei Faxin et al. [5] (Beijing) first reported a case of insufficient HIV antibodies affecting diagnosis in 2007. This case involved a 37 -year old male patient who had a positive ELISA result, but an indeterminant WB result-only the gp160 band was observed. This was insufficient evidence for an HIV diagnosis based on the HIV testing algorithm at that time. However, the patient reported male-male sexual contact, and presented with symptoms that were consistent with the typical manifestation of AIDS, including Pneumocystis carinii pneumonia and mucosal fungal infections. Therefore, to further explore a diagnosis of HIV infection, a second blood sample was obtained and tested for HIV antibodies, HIV viral load (VL), and CD4 count. Antibody results remained unchanged. However, VL was 153,000 copies/mL, and CD 4 count was only 5 cells $/ \mu \mathrm{l}$, and thus, the patient was diagnosed with HIV infection and AIDS. Another case was reported by Zhang YunZhi et al. [6] (Shanghai) in 2008 involving a16-month-old child born to a mother with HIV infection.

The infant was tested several times for HIV infection using rapid antibody test kits and results were consistently negative despite the child having multiple AIDS-related symptoms. Eventually, the child was diagnosed with HIV infection by quatitative nucleic acid testing. In 2010, Li Yan et al. [7] (Guangdong) reported on the case of a 33-year-old female patient who had tested a positive result by HIV ELISA, but indeterminant by HIV WB-only the p24 band was detected. Her husband was diagnosed with AIDS in June 2005, she accepted an HIV antibody test. Based on obvious family transmission that her husband was HIV positive before her antibody test and clinical manifestations of AIDS complications such as fungi, monilial infection, and pneumonia, VL and CD4 testing was ordered. VL result was $>1,000,000$ copies/mL and CD4 cell count result was 7 cells $/ \mu \mathrm{L}$, and hence, the patient was diagnosed with HIV infection.

In 2012, Qin Yingmei et al. [8] (Guangxi) reported on a 69-yearold male patient, who had been diagnosed with HIV infection in 2011, and had progressed to AIDS as evidenced by his having a variety of opportunistic infections including tuberculosis, shingles, and others. He also exhibited a serious loss of HIV antibodies. During follow-up WB testing, the typical bands indicating HIV infection decreased in number and intensity, and finally only the gp160 band remained, indicating that the level of antibodies has decreased over the course of AIDS progression. Most recently in 2017, Zhang Hong et al. [9] (Beijing) reported on the case of a 46-year-old male patient with a positive HIV ELISA result and Kaposi's sarcoma, yet had a negative HIV WB result. The patient was then tested for HIV VL and CD4 count. His VL was 42,969 copies/mL, his CD4 count was 6 cells/ $\mu \mathrm{L}$, and therefore he was diagnosed with HIV infection.

\section{Cases Reported Elsewhere}

Outside of China, a review was published in the journal AIDS in 2010 by Spivak et al. [10] which identified 25 cases of HIV infection worldwide between 1994 and 2009, where HIV antibody-based testing methods yielded negative or uncertain results. All of these patients had two or more negative results on HIV ELISA testing yet had positive results on antigen or nucleic acid testing. Another 4 cases were reviewed, they were N0.27,32-34 cases in Table 1. N0.27 case reported in 2008, but not included in Spivak et al. [10] review, was found in a paper published by Ortiz de Lejarazu et al. [11] In this case, a 28-year-old male presented with Kaposi's sarcoma and Pneumocystis carinii pneumonia. Both HIV rapid testing and HIV ELISA testing results were negative, but his VL was 122,000 copies/ mL and CD 4 count was only 4 cells/ $\mu$ L. Between 2010 and 2017, we were only able to find 3 additional cases of HIV patients with false negative antibody tests, one from Iran and two from Spain, they were N0.32-34 cases in Table 1.

\section{Discussion}

In summary, "uncertain" or even "negative" results of HIV antibody-based testing methods should be questioned when HIV disease-related symptoms or opportunistic infections are present and/or when the patient is identified as being at high risk of HIV infection. Although it is rare that individuals would be tested in the "window period" of acute, early infection or after progressing into advanced AIDS disease, when quantities of circulating antibodies are very low, the likelihood of false-negative/uncertain results should not be ignored. For diagnosis verification, HIV nucleic acid testing is the most convincing indicator. Viral replication will continue even as quantity and diversity of antibody levels decline and HIV nucleic acid testing can be used as an effective, reliable method to verify HIV diagnosis.

Due to technical and financial constraints, HIV nucleic acid testing currently is underused as a diagnostic tool for HIV infection in China and elsewhere. However, to prevent misdiagnosis and treatment delay, we recommend it be used to help diagnose patients suspected of being in the very early stages of HIV infection and those who present with HIV disease-related symptoms and opportunistic infections common in the advanced stages of AIDS in China [12]. This recommendation has been documented by the Third Edition of AIDS Diagnosis and Treatment Guidelines (2015) of China [13]. HIV nucleic acid testing was also included as a confirmation strategy and part of the algorithm for the HIV confirmation process in the National Guideline for Detection of HIV/AIDS revised by the China CDC in 2015 of China [14].

\section{Conclusion}

We summarize 34 cases with seronegative or uncertain HIV antibody testing results using ELISA or WB methods, which were reported internationally between 1994 and 2017. Five of these cases were reported by China. Although all cases were antibodynegative or uncertain, nucleic acid testing results were positive, CD4 cell counts were low, and typical HIV-related complications and opportunistic infections were present in all cases. These cases 
demonstrate the crucial need for HIV nucleic acid qualitative or quantitative detection for diagnosis of HIV infection when antibodybased methods yield negative or uncertain results.

\section{Conflict of Interest}

None.

\section{References}

1. Meiguang Zhang (2004) Discussion on Changes in the Antibody Level and Loss of Specific Interferors in Patients before and after the Attack of AIDS. Clinical Medicine 24(10): 10-11.

2. Mylonakis E, Paliou M, Rkh JD (2001) Plasma viral load testing in the management of HIV infection. Am Fam Physician 63(3): 483-491.

3. Shah I (2006) Effieacy of HIV PCR techniques to diagnose HIV in infants born to HIV infected mothers-an Indian perspecitve. J Assoc Physicians India 54: 197-199.

4. Adam M Spivak, Emily RM Sydnor, Joel N Blankson, Joel E Gallant (2010) Seronegative HIV-1 infection: a review of the literature. AIDS 24(10): 1407-1414.

5. Faxin Hei, Qiyun Zhang, Weidong Sun (2007) Apply Viral Load to Diagnosis of AIDS Cases with Loss of Antibody. Chinese Journal of AIDS \& STD 13(3): 264-265.

6. Zhang Y, Wang J, Wilson GJ, Tang YW, Lu HZ (2008) Negative results of a rapid antibody test for HIV in a 16-month-old infant with AIDS. Annals of Clinical and Laboratory Science 38(3): 293-295.

7. Yan Li, Jin Kou Zhao, Ming Wang, Han ZG, Cai WP, et al. (2010) Current antibody-based immunoassay algorithm failed to confirm three latestage AIDS cases in China: case report. Virol J 15(7): 58.

8. Yingmei Xiangchan Lu, Yingxing Nong (2012) A Report on AIDS with Confirmed Negative Anti-HIV. Chinese Journal of New Clinical Medicine 5(4): 353-354.

9. Zhang H, Wang HL, Zhong DR, Liu Y, Li NN, et al. (2017) Fatal pulmonary Kaposi sarcoma in an HIV seronegative AIDS patient. Clin Respir J 11(6): 1040-1044

10. Spivak AM, Brennan T, O'Connell K, Emily Sydnor, Thomas M Williams, et al. (2010) A case of seronegative HIV-1 infection. J Infect Dis 201(3): 341-345.

11. Ortiz de Lejarazu R, Soriano V, Eiros JM, José M Eiros, Manuel Arias, Carlos Toro (2008) HIV-1 infection in persistently HIV-1-seronegative individuals: more reasons for HIV RNA screening. Clin Infect Dis 46(5): 785.

12. Faxin Hei, Hailin Liu, Weidong Sun (2008) Differential Diagnosis of Early HIV Infection via Viral Load Detection. Chinese Journal of Microbiology and Immunology 28(6): 557-559.

13. (2008) Diagnostic Criteria of AIDS and HIV infection WS 293-2008. Ministry of Health of the People's Republic of China.

14. Faxin Hei, Lu Wang (2010) Application of Viral Load Detection in Difficult Sample Diagnosis of HIV/AIDS Antibody. Chinese Journal of AIDS \& STD 16(3): 323-325.

15. (2015) AIDS Group, Society of Infectious Diseases, CMA. ( $3^{\text {rd }}$ edn.). of the Guidelines for Diagnosis and Treatment of HIV/AIDS. Chinese Journal of Clinical Infectious Diseases 8(5): 385-401.

16. Yan Jiang, Ning Wang, Jingyun, Li (2015) National Guideline for Detection of HIV/AIDS (2015). Chinese Center for Disease Control and Prevention.

17. Soriano V, Dronda F, Gonzalez Lopez A, Chaves F, Bravo R, et al. (1994) HIV-1 causing AIDS and death in a seronegative individual. Vox Sang 67(4): 410-411.

18. Oka S, Ida S, Shioda T, Takebe Y, Kobayashi N, et al. (1994) Genetic analysis of HIV-1 during rapid progression to AIDS in an apparently healthy man. AIDS Res Hum Retroviruses 10(3): 271-277.
19. Wegner S, Ohl C, De Nobile J (1995) Case Report of a woman with seronegative HIV-1 infection. AIDS Res Hum Retroviruses 11 (Suppl 1): S107.

20. Martin Rico P, Pedersen C, Skinhoj P, Nielsen C, Lindhardt BO (1995) Rapid development of AIDS in an HIV-1-antibody-negative homosexual man. AIDS 9(1): 95-96.

21. Reimer L, Mottice S, Schable C, A Sullivan P, Nakashima A, et al. (1997) Absence of detectable antibody in a patient infected with human immunodeficiency virus. Clin Infect Dis 25(1): 98-100.

22. Montagnier L, Brenner C, Chamaret S, Guétard D, Blanchard A, et al. (1997) Human immunodeficiency virus infection and AIDS in a person with negative serology. J Infect Dis 175(4): 955-959.

23. Michael NL, Brown AE, Voigt RF, Frankel SS, Mascola JR, et al. (1997) Rapid disease progression without seroconversion following primary human immunodeficiency virus type 1 infection: evidence for highly susceptible human hosts. J Infect Dis 175(6): 1352-1359.

24. Quinonez JM, Begue RE, Steele RW (1998) HIV seronegativity in an infant with the acquired immunodeficiency syndrome. South Med J 91(9): 879-881.

25. Sullivan PS, Schable C, Koch W, Do AN, Spira T, et al. (1999) Persistently negative HIV-1 antibody enzyme immunoassay screening results for patients with HIV-1 infection and AIDS: serologic, clinical, and virologic results. Seronegative AIDS Clinical Study Group. AIDS 13(1): 89-96.

26. Rice PS, Cybulska B, Parry JV, Rowland Jones S, Daniels RS (1999) Reappearance of HIV antibody in an infected, seronegative individual after treatment with highly active antiretroviral therapy. AIDS 13(6): 729-731.

27. Ellenberger DL, Sullivan PS, Dorn J, Schable C, Spira TJ, et al. (1999) Viral and immunologic examination of human immunodeficiency virus type 1-infected, persistently seronegative persons. J Infect Dis 180(4): 10331042 .

28. Candotti D, Adu Sarkodie Y, Davies F, Baldrich Rubio E, Stirrups K, et al. (2000) AIDS in an HIV-seronegative Ghanaian woman with intersubtype A/G recombinant HIV-1 infection. J Med Virol 62(1): 1-8.

29. De Rossi A, Giaquinto C, Del Mistro A (2000) Onset of HIV-1 antibody production after highly active antiretroviral therapy in a seronegative HIV-1-infected child. AIDS 14: 1284-1286.

30. Cardoso AR, Goncalves C, Pascoalinho D, Gil C, Ferreira AF, et al. (2004) Seronegative infection and AIDS caused by an A2 subsubtype HIV-1. AIDS 18(7): 1071-1074.

31. Monkemuller K, Fry LC, Decker JM, Rickes S, Smith PD (2007) Severe gastrointestinal disease due to HIV-1-seronegative AIDS. Z Gastroenterol 45: 706-709.

32. Chin BS, Lee SH, Kim GJ, Kee MK, Suh SD (2007) Early identification of seronegative human immunodeficiency virus type 1 infection with severe presentation. J Clin Microbiol 45(5): 1659-1662.

33. Novitsky V, Gaolathe T, Woldegabriel E, Makhema J, Essex M et al. (2007) A seronegative case of HIV-1 subtype C infection in Botswana. Clin Infect Dis 45(5): e68-e71.

34. Dalmau J, Puertas MC, Azuara M, Mariño A, Frahm N, et al. (2009) Contribution of immunological and virological factors to extremely severe primary HIV type 1 infection. Clin Infect Dis 48(2): 229-238.

35. Bartolo I, Camacho R, Barroso H, Bezerra V, Taveira N (2009) Rapid clinical progression to AIDS and death in a persistently seronegative HIV-1 infected heterosexual young man. AIDS 23(17): 2359-2362.

36. Eftekhari K, Say EA, Shields CL, Gausas RE, Shields JA (2011) Orbital lymphoma in the setting of idiopathic CD4+ lymphocytopenia (HIVnegative AIDS). Ophthal Plast Reconstr Surg 27(5): e134-e136.

37. Ollé Goig JE, Ramírez J, Cervera C, Miró JM (2012) Profound reduction of CD4+ lymphocytes without HIV infection: two cases from the horn of Africa 12(3): 331-333. 
ISSN: 2574-1241

DOI: 10.26717/BJSTR.2019.20.003423

Jun Hu. Biomed J Sci \& Tech Res

(C) (P) This work is licensed under Creative

Submission Link: https://biomedres.us/submit-manuscript.php

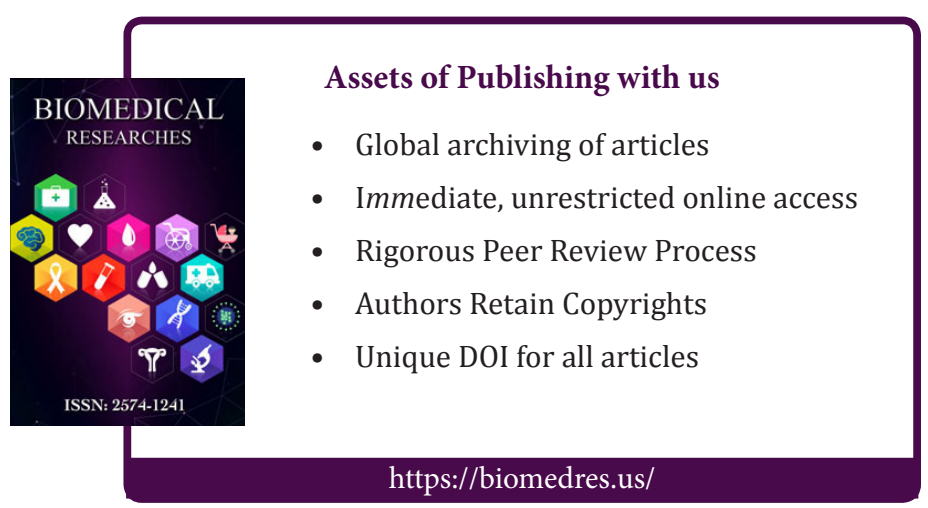

